\title{
Thesiontid
}

\section{(Re)Inventar: Leitmotiv arquitetônico}

Fernando Atique, Lidia Quiéto Viana, Marcio Cotrim e Rachel Coutinho Marques da Silva

É muito antiga e recorrente a ideia de que a profissão do arquiteto e urbanista se ancora na invenção. Este substantivo feminino denota aquilo que se criou, se elaborou com ímpeto ou mesmo se deu processualmente visando a criação de algo. Exprime, assim, um surgimento social que passa a ser notável, e que se vincula à existência, visando alterá-la. O número 10 da revista Thésis, traz, em seu escopo, esta discussão em todas as suas seções.

Vivemos tempos complexos. Experimentamos a mais grave crise sanitária do século XXI, e a mais impactante dos últimos cem anos. Forçosamente, fomos conduzidos a uma reorganização dos ritos, dos espaços e dos tempos, de maneira a acomodar demandas que abruptamente se instalaram em nossa rotina. Procedimentos corriqueiros foram transportados para uma dimensão completamente digital, e a experiência urbana foi sendo filtrada por protocolos sanitários e eletrônicos. Estas situações desencadearam novas posturas pessoais e profissionais e conduziram-nos, curiosamente, de volta ao leitmotiv da profissão arquitetônica: a (re)invenção. Como um tema musical, que é retomado ao longo de uma sinfonia, a reinvenção da carreira e da prática profissional desafiam-nos, mais uma vez. A história da profissão do arquiteto e urbanista é permeada por tensões criativas que não apenas alteraram a estrutura compositiva do projeto de arquitetura e de urbanismo, como abriram novas perspectivas, englobando temas, materiais, sistemas construtivos e a delimitação da ética.

Pensar, então, este número 10 da Thésis, nos possibilitou a costura de reflexões com temporalidades muito diversas, mas que lidaram com tensões sociais e profissionais e podem nos ajudar a formular saídas para a crise em que estamos mergulhados. Criatividade na abordagem, na enunciação dos problemas e na 
proposição de soluções mobilizam as nossas universidades e se refletem nas páginas deste número da revista da ANPARQ.

A seção Ensaios traz 4 artigos, que lidando com objetos muito diversos, convergem para reflexões importantes acerca dos limites entre tempos idos e tempos vindouros. Abordam, em última instância, momentos decisivos para a mudança, ora abordando estruturas em colapsos, ora em recrudescimentos sociais. 0 primeiro artigo deste número é de autoria de Sandra Catharinne Pantaleão Resende, da PUC-Goiás, intitulado Factoring Cities: Paisagens urbanas a partir de discurso-diagnóstico na era financeira digital, em que a obra de Rem Koolhaas é abordada visando a compreensão "da lógica de consumo que orienta grande parte das intervenções urbanas, além dos processos de urbanização em pontos estratégicos do planeta condicionados à globalização, às tecnologias de informação e ao mercado financeiro". Uma reflexão muito importante sobre o modo urbanizador da sociedade contemporânea.

O segundo artigo da seção, de Daniel Mellado Paz, da FAU-UFBA, de nome O Alfa e o Ômega: A vida das grandes cidades, suas fases e porque deveriam nos importar, enfoca a produção da ativista estadunidense Jane Jacobs escrutinando sua compreensão por "vitalidade urbana", uma dimensão, que, segundo o autor, expressam uma "inovação epistemológica". Discutir Jacobs e suas críticas às subordinações urbanas a lógicas não vitais de permanência é um desafio que também se reinsere na atualidade.

O terceiro artigo, redigido por Rafael Gomes e Giselle Azevedo, do PROARQ/FAU-UFRJ, denominado Dos territórios vulneráveis aos territórios educativos, discorre acerca da necessária "união da escola e da cidade em prol da educação", o que "pode representar uma ação importante contra os diversos problemas decorrentes das desigualdades sociais", algo que só ganhará envergadura transformadora por meio dessa união em "abrangência territorial".

Por fim, o quarto artigo, Mies e a primazia das relações entre espaço, estrutura e fechamento, da professora da FAU-UFRJ, Mara Eskinazi, analisa seis casas unifamiliares projetadas por Mies van der Rohe, abordando as decisões miesianas no que compete à criação das fachadas, uma vez que elas expressam "suas diferentes formas de abordar a resolução de conflitos entre espaço, estrutura e fechamento". 
A seção Arquivo traz a tradução inédita de três verbetes do Dictionnaire d'Architecture, produzido pelo francês Quatremère de Quincy, em 1788. A tradução é de responsabilidade da professora da PUCCampinas, Renata Baesso Pereira, e veicula aos leitores de língua portuguesa as definições iluministas de "Copiar", "Imitação" e "Invenção". Como expõe Baesso Pereira, a escolha "dos verbetes é pautada pela intenção de investigar alguns dos termos através dos quais Quatremère de Quincy define a natureza e a finalidade da Arquitetura, o papel do gênio na criação de novas obras, bem como o da imitação e da invenção dentro de um sistema de princípios e regras". Ou seja, trazem as reflexões que ainda hoje são necessárias à prática profissional.

Estes verbetes foram a base para a criação da seção Passagens, mais uma vez a cargo do professor da Escola de Arquitetura da UFMG, Mateus Rosada, que convidou os colegas José Clewton do Nascimento, do Curso de Arquitetura e Urbanismo da UFRN, e André Lissonger, da FAU-UFBA, todos vinculados ao movimento Urban Sketchers Brasil. A reflexão dos colegas, encabeçada por breve suporte textual de Rosada, de nome Forma, Autenticidade e Padrão na Arquitetura, explora as conexões entre o tempo e o classicismo. Para Rosada, "não é porque há esse aspecto datado que os escritos de Quatremère não deixam de ser atuais". Conforme aponta, os "três verbetes - Copiar, Imitação e Invenção - tratam de conceitos atemporais para a arquitetura, pois são intrínsecos ao próprio fazer arquitetônico e à essência da profissão". E, mais uma vez, aparece o leitmotiv deste número da Thésis: "sendo assim, nos levam a (re) pensar a arquitetura como conjunto de saberes."

A seção Recensão é composta por duas resenhas. A primeira resenha escrita por Ana Luiza Nobre, docente no Programa de Pós-Graduação em Arquitetura da PUC-Rio, explora o legado do arquiteto lusitano Diogo Seixas Lopes (1972-2016), editada "por seu amigo e interlocutor André Tavares", e lançada em fins de 2019, pela Dafne Editora, do Porto. Como expõe Nobre, o livro é monumental, tanto em sua dimensão discursiva, quanto gráfica, e se inscreve em uma estratégia coletiva de infundir a arquitetura portuguesa mundo afora. Desta maneira, o título escolhido Diogo Seixas Lopes: Sinal vital explora muito bem o que está em jogo com este tipo de projeto editorial.

A segunda resenha foi escrita pelo professor do Programa de Pós-Graduação em Arquitetura da PUC-Rio -- Otavio Leonídio, que analisa a tese menção honrosa 
no Prêmio CAPES de Tese na edição 2019. O texto de Leonídio, intitulado De Volta ao Pós-Modernismo, aborda o trabalho defendido por Guilherme Essvein de Almeida, no PROPAR-UFRGS, com orientação do Prof. Dr. Carlos Eduardo Dias Comas. A tese, intitulada A Casa da Música e a Cidade das Artes Rio: por uma monumentalidade, "se ocupa de algumas das questões centrais da agenda pós-modernista em arquitetura, com destaque para o problema da continuidade (mas também da descontinuidade) histórica", como pontua Leonídio. O trabalho debate com profundidade e senso crítico as obras de Koolhaas e Portzamparc, constituindo-se, como observou Leonídio, numa "importante contribuição ao debate sobre os múltiplos caminhos, continuidades e descontinuidades da arquitetura pós-pós-modernista, demonstrando de modo convincente que muitas das questões levantadas no debate pós-modernista dos anos 1980 continuam válidas e esperando novas respostas". Esta resenha ensejou a escolha da capa desta edição, que publica o desenho extraído do livro de Charles Jencks, The Iconic Building: The power of enigma.

Inseridos na reinvenção que nos é impelida em múltiplas frentes, desejamos a todos uma ótima leitura da Thésis número 10 . 